\title{
Inter Arma Non Silent Musae: Shakespeare as a Symbol of the Czech Pro-Allied Attitude during the Great War
}

\begin{abstract}
This article attempts to trace the reception of selected Shakespearean performances in theatre reviews published in period newspapers in terms of critical response embedded in a broader social and political context of the Shakespeare festival held at the National Theatre in Prague in 1916. The Festival was arranged to celebrate the tercentenary of Shakespeare's death. As seen against the backdrop of the Great War, it was understood not only as a great theatrical achievement, but most importantly as a presentation of the Czech national self-awareness and identity. It furthermore attempted to strengthen the autonomy of the Czech theatres and demonstrated the Czech pro-Allied sympathies. Using period theatre reviews anchored in the historical background and framed within the theoretical context of reception aesthetics, this article aims to reveal and interpret some of the elements underpinning selected Shakespearean performances.
\end{abstract}

Key words

Reception Aesthetics; critical reception; Shakespearean adaptations; Great War; Czech Lands

\section{Introduction}

During the Great War, theatres served as a platform for the awareness of national identity by preserving traditional and cultural values. They attempted to arouse national enthusiasm and support national feelings against the Austro-Hungarian oppression. In Pilsen, the rebellious spirit was further fuelled by Josef Skupa's marionette, the so-called "Revolutionary Kašpárek", which symbolised the Czech 
national heritage (Mišterová 2010: 177). Although theatres found themselves in the grip of censorship, the repertoire was oriented more towards the democratic drama (e.g., Shaw, Shakespeare, etc.) and plays showing the national strength and courage (e.g., Tyl, Jirásek, Klicpera, Vrchlický, etc.). In many productions of the time, it is possible to trace theatrical attempts to break through autocratic restrictions and to establish closer contact with the audiences (e.g., Hamlet, Richard III, and Macbeth staged at the National Theatre in Prague in 1916).

This article aims to explore the Shakespeare Festival, which was held at the National Theatre in Prague in 1916. Based on the audience response theory, it attempts to trace distinctive features of particular Shakespearean performances in the Czech national context, and also to argue that Shakespeare's plays performed at that time specifically reflected the Czech world of politics.

\section{Historical terminus a quo}

The outbreak of the Great War eventually evoked the long-lasting Czech aspirations to attain sovereignty by disentangling it from Austria-Hungary. However, the road to independence was still long and difficult.

The assassination of Franz Ferdinand d'Este (Archduke of Austria and successor to the throne) and his wife Sophie on 28 June 1914, committed by the Serbian Nationalist terrorist group, known as the Black Hand in Sarajevo, provided the initial impetus for the outbreak of war. Events of the war soon accelerated with the involvement of all great European powers fighting either on the side of the Allies or the Central Powers. Having started as an Austro-Hungarian military conflict with Serbia, it gradually encompassed almost two-thirds of the world. Czech citizens had initially responded to the outbreak of war with detachment, doubt, curiosity, and patriotic enthusiasm, which gradually changed into an antiwar attitude. ${ }^{1}$ Although war operations did not take place directly in Bohemia and Moravia, the population had to endure many hardships, such as the shortage of food and coal supplies, the enormous rise in prices, illnesses, and profiteering (Čornej 1992: 38). In April 1915, a rationing system was introduced to restrict the demand for certain commodities such as bread, milk, meat, coffee, soap, and many others. An extremely wet summer in 1916 caused a catastrophic crop failure, which further increased the cost of grain. Deteriorating economic conditions provoked waves of protests, strikes, and demonstrations. Food riots that broke out throughout the country from 1916 to 1918 were violently suppressed and had tragic consequences.

The entry of Austria-Hungary into the war led to a complete fragmentation and paralysis of the Czech political scene. The Czech political parties' membership base was seriously threatened by a large war mobilization and persecution of both the actual as well as alleged enemies of the regime. Additionally, during the initial weeks of the Great War, many important periodicals ceased publication (see below). Many prominent political, social, and cultural representatives were 
arrested in order to suppress the growing pro-Russian and pan-Slavic tendencies among the Czech population. In 1915, the youth sport movement Sokol was banned. Yet, the anti-Austrian resistance developed both in the country as well as abroad. Unlike a rather hesitant inland opposition, the foreign anti-Austrian campaign, started by Tomáš Garrigue Masaryk in Geneva in July 1915, was based on a clear and compelling vision of constituting a new autonomous Czechoslovak state. Meanwhile, Masaryk and his co-workers (Edvard Beneš and Milan Rastislav Štefánik) gained the needed international support (Čornej 1992: 39). Subsequently, the Czechoslovak National Council was established in Paris in 1916 along with the remarkable rise of Czechoslovak Military Legions formed from war deserters and foreign compatriots, fighting on the side of the Allies against the Central Powers.

However, some progress was noticed in the Czech Lands. The representatives of the domestic resistance movement founded a clandestine resistance organization (the so-called "Maffia") that strived to join forces with the foreign anti-Austrian resistance. The pace of events quickened when the United States declared war on Austria-Hungary in December 1917. This consequently led to the gradual termination of the war. The anti-Austrian tendencies culminated in 1918, with the Epiphany Declaration, issued in Prague on 6 January 1918. The declaration laid emphasis on self-determination of the Czech nation and its integration with Slovakia. On 30 May 1918, the Pittsburgh Agreement approved the integration of Czech Lands with Slovakia, thus forming one independent country. The establishment of the autonomous Czechoslovak state was eventually declared by representatives of the Czech National Council on 28 October 1918. Finally, after four years of fighting and hardship, the Czech Lands became independent.

\section{Theoretical framework: reception aesthetics}

Before examining particular Shakespearean productions, an extended discussion of some basic theoretical principles is necessary. The methodological approach is closely related to the assumption that there exists a correlation (in fact, more or less directly proportional) between periodical events, theatrical productions, and audience responses. Basic reasoning behind this proposition is the idea that a dramatic text is brought into existence through the convergence of a text, a performance, and the theatre audience, advocated by the representatives of the Constance School of Reception Aesthetics, Hans Robert Jauss and Wolfgang Iser. The School of Reception Aesthetics came into existence in Germany during the turbulent 1960s, when a new educational reform called for a rethinking of traditional educational approaches and methods. The newly founded Constance University (1967) provided a stimulating atmosphere in which new ideas could develop and flourish. Although reception theory dominated literary criticism in Germany for more than a decade, it was, in fact, unknown to the English-speaking world up to the 1980s when translations into English made it more accessible to literary scholars. ${ }^{2}$ 
Jauss's reception aesthetics (Rezeptionästhetik) underscores the role of the recipient in the production and reception of art, and argues against the objectivism of historical positivism, the essentialism of all substantialist notions of art, and the notion of art as art for art's sake (Rush 1997: 65-66). As viewed from Jauss's perspective, the final form and meaning of a work, which does not exist for its own sake, but has a social function and impact, is achieved through the process of interpretation and reception. A work is thus constituted through a mutual, dynamic interaction between author, text and reader. Although Jauss treats these three agents as being equally important, the role of the recipient as a "mediator" or "creator" of the text obviously comes to the forefront. In Jauss's discourse, the term "recipient" is not, however, limited only to the reader, but also refers to the listener, spectator, viewer, and, broadly speaking, to any receiver of art. In the present study, the notion of the recipient will be extended to a theatre critic, in whose perception, a spectator's reception, is juxtaposed with critical interpretation. The recipient's aesthetic reception of a work subsequently interconnects not only the act of reception and the given work, but also the history of art itself (Rush 1997: 67).

Jauss develops his concept of reception aesthetics through the notion of the horizon of expectations (Erwartungshorizont) and the relationship between poiesis - aesthesis - and catharsis. Although it is not given a precise definition, a horizon of expectations may be understood as "an intersubjective system or structure of expectations, a system of references, or a mind-set that a hypothetical individual brings to a given text" (Holub 1995: 323). In other words, it comprises the criteria that are used by the recipient to evaluate a work at a given period in history. These criteria, which fall into three categories (generic, literary, and linguistic) are, in fact, (pre)determined by literary conventions and norms of the time. Jauss emphasises the fact that literary conventions and, as one might add, cultural tastes, change over history. Thus, a work may be initially rejected when its horizon of expectations is identified as alien, but can gradually become accepted, having created new horizons of expectations. On the other hand, the initially accepted work may later be rejected due to newly-evolving norms and conventions.

A horizon of expectations is, in Jauss's view, associated with a horizon of lived experience, which comprises assumptions of the social and cultural world, and an individual horizon of expectation, which consists of a set of assumptions held by the recipient (theories that focus on the influence of the personality of the recipient are almost exclusively psychological, taking into consideration personality trait factors). In the process of reception, new horizons constantly emerge and change depending on the signals sent by the text. Change in the horizon of expectations, which increases under conditions of confrontation with a work, is manifested through different critical reactions towards text, e.g., success, rejection, failure, surprise, shock and understanding, which, at the same time, indicate the aesthetic value of the work. The concept of the distance between a horizon of expectations and a literary work is not exclusively Jauss's concept, but follows up on the alienation effect (Verfremdung, ostranenie) introduced and developed 
by Russian Formalism. The closer the reaction corresponds with the horizon, the more likely the work is to be low literature, culinary art or pulp art. To prevent great works of art from being reduced to culinary art, it is necessary, as Jauss (2007: 25-26) puts it, to "read them against the grain of the accustomed experience to catch sight of their artistic character once again."

Robert Holub (1995: 324) points out that the reconstruction of the horizon of expectations by the recipient seems to be problematic (and biased), since a horizon is reconstructed based on texts that are subsequently to be judged against the horizon that they previously helped to create. Equally problematic, in my view, is to what extent both a horizon and work are resistant to change. For Jauss, change is a natural state of the horizon yet some general tendency towards stability cannot be denied. Moreover, mechanisms for change and (at least certain) stability reside both within the horizon and the work as well as within their environment. Being aware of a certain stolidity of his concept, Jauss later redefined the recipient's role as emerging from two horizons of expectations, the literary horizon, which arises during the act of reading, and the social horizon of the recipient (Bennett 2003: 50).

Notwithstanding some methodological ambiguity, Jauss's concept will be used to demonstrate that a horizon of expectations is conditioned both by temporal, cultural, and spatial factors and by individual abilities of the recipient. Further, in this article, it will be shown how Shakespearean productions were received by Czech theatre critics during the Great War. To achieve greater efficiency, Jauss's vertical (or sequence) model work - reception - work will be complemented with a horizontal model (as highlighted by the author), describing the period reception of particular works (i.e., performances) of the same genre (i.e., Shakespearean drama) in the same period (in 1916). It will be shown that, apart from enthusiastic reception, it also offered a partly polemical response, even though it originally served a commemorative purpose.

Similar to Jauss, Wolfgang Iser also accentuated the interaction between text and recipient, and its result. In his view, a literary work is neither a pure text nor the recipient's subjective perception, but rather the product of their merge. In this respect, he sets out three areas to be examined: the potential of text to produce meaning, the act of reading per se, and conditions that give rise to and affect the recipient-text interaction. In contrast to Jauss, Iser "decontextualizes and dehistoricizes" the text (Selden, Widdowson, and Brooker 2005: 52). He perceives it as a skeleton, which has to be updated and concretised by the recipient based on his/her experience and extra-literary norms and values. Thus, meaning is created during the process of making sense of the recipient's dialectical relationship to the text. The same applies to a theatrical performance, which may be accordingly seen as a referential structure, requiring actualisation and concretisation as well. ${ }^{3}$ In this case, not only recipients participate in the process of completion, but also actors, who, themselves, create dramatic configurations on stage. A specific role in the process of production of meaning is played by translation (see below).

Iser is, nevertheless, critical of a simplified vision of the text as a reflection of the outside world. He is convinced that "the literary text can never be fully 
identified either with the objects of the external world or with the experiences of the reader" (1993: 7). This insufficient identification causes a certain degree of indeterminacy, which is, nevertheless, gradually counterbalanced by the recipient during the reading/watching process. Filling in the gaps in text, or "places of indeterminacy", as Roman Ingarden calls them, with meaning (Holub 1995: 327-328), is not a mechanical activity, but urges the recipient to combine particular segments of the text and various perspectives on their representation. Furthermore, the recipient is required to make hypotheses, which concern the mutual relationships between these segments and perspectives, and, at the same time, govern and control activities of the recipient, who finally creates notions and images. As Iser points out,

These gaps give the reader a chance to build his own bridges, relating the different aspects of the object which has thus far been revealed to him... The indeterminate sections, or gaps of literary texts are in no way to be regarded as a defect; on the contrary, they are a basic element for the aesthetic response. Generally, the reader will not even be aware of them ... Nevertheless, they influence his reading, for the "schematized views" are continually connected with each other by the reading process. This means that the reader fills in the remaining gaps. He removes them by a free play of meaningprojection and thus himself provides the unformulated connections between the particular views. (Iser 1993: 9-10)

Furthermore, it may be argued that these gaps generate tensions, which affect the recipient's reactions. Consequently, a number of various solutions (=completions) arise. Yet they are not created at random, but are anchored in the systemic reference of the text structure, which is constantly open to intersubjective reconstruction (Nünning, Trávníček, and Holý 2006: 517). In this regard, Iser distinguishes between an implied reader and an actual reader. The implied reader is a theoretical construct, a hypothetical reader, who possesses the qualities that are created by the text and are, at the same time, necessary for the work to have the required effect. It, moreover, serves to contextualise the work within a particular temporal and spatial background. In contrast to the previous one, the actual (or real) reader completes the meaning of the text based on the signals sent by the text. This completion is coloured by the recipient's own experience and perception.

When applied to theatre reception, it is obvious that the real spectator will bring to a theatrical performance his/her own experience and values that will help them shape their perception. Thus, each performance (similar to each reading) produces a different interpretation, which contributes to a better understanding of the work. Given the considerable distance of the period under consideration, the insight into selected Shakespearean performances will be gained through period critical reviews. Here, inevitably, the task of the critic to explain what effect the text has on its recipient rather than to explicate it as an aesthetic object comes to the fore. Though probably subjective in nature, the critical assessment of the 
performances will help shed light on the reception of performances at a given time. The following section provides an in-depth discussion of theatrical reviews and outlines both advantages and disadvantages of using them as primary sources in performance reception.

\subsection{Theatrical reviews}

A theatrical review is a relatively important source of information on how the performance was staged. Although it brings a critical judgement, which may affect the overall reception of the performance in both a positive and negative way, the performance's narrative, as Hardwick calls it, is, at least, to some extent, "subject both to the vagaries and selectivity of the visual and aural memory of the reviewer and to his or her subjective comments" (Hardwick 2003: 54). Equally deceptive may be the degree of the critic's personal preoccupation with a play/performance. Moreover, there appears to be a thin line between an ideological judgement and the one based on aesthetic criteria. Being bound by the policy of the publishing periodical, the review may, albeit, not necessarily, reflect the journal's views and stance. Thus, ideally, as Patrice Pavis (1982: 104) insists, the critic should be the "voice for the arts", at least partially freed from political and ideological assumptions and considerations. Another essential issue is that of censorship, preventing the publication of reviews that do not adhere to government regulations or undermine the regime (see below). No less important is a particular point in time when the review was written. A premiere, without doubt, produces a different impression than a repeat or final performance. Besides this, the focus and structure of the review vary on the basis of the critic's intention and his/her field of expertise (critic-historian, critic-literary scholar, critic-theatre scholar, artist, playwright, etc.), which may add a specific flavour to the commentary or even carry it beyond its required scope. In a sense, a review serves as a connecting link between a performance and audience (and possibly a future audience). Finally, it should not be forgotten that a review serves an entertaining function and, as Helen Freshwater observes (2009: 36), is allotted a limited space and is subject to given deadlines.

Thus, a theatrical review needs to be understood as a significant documentary source (though not a completely neutral one), which sheds light on the intentions of theatre practitioners, individual artistic performances, stage history of a play, circumstances under which the performance was staged, and broader cultural and economic conditions governing the performance. In the case of performances staged in translation, reviews also focus on the accuracy of the interlingual transfer, especially in terms of speakability and performability. Yet, obviously, for many spectators, the translation is the only means of access to the source text. In contrast to theatre/literary critics, "ordinary" spectators naturally pay more attention to speakability and performability of the translated text than to faithfulness or fidelity to the original, with which they may not be acquainted.

The use of period theatre reviews as a basis for research involves methodological obstacles. In many cases, the information provided is often limited to the brief 
depiction of costumes, set design, directorial intention, and individual artistic performances. Therefore, it is important to juxtapose critical reviews of the same performance (if they are available) to obtain a more comprehensive and objective portrayal. Reviews help to reconstruct the horizon of expectations of the original recipients (i. e. critics) and help us to grasp how they would have understood the performance. However, our reconstruction of their experience will never be identical to their understanding since our reconstruction of their understanding and experience will take place within our contemporary horizon of expectations. The reconstruction becomes even more complicated due to rigid censorship restrictions, which were imposed by the Austro-Hungarian monarchy during the Great War.

Press censorship, which was supervised by the Foreign Ministry, the Interior Ministry, the Ministry of Justice, and the Ministry of Finance and the Army, contained two main sub-sections, the political press censorship and the military press censorship (Šedivý 2001: 50). The control of periodicals was largely left to the public prosecutor, who was supposed to work in partnership with police chiefs, police commissioners, and other government authorities. Newspapers in the Czech Lands were obliged to submit daily press three hours prior to release. The Interior Ministry ordered censors to heed the support of patriotic [pro-Austrian] spirit, record the heroic exploits of the war, and to suppress nationalist and social strives. However, readers soon learned to catch various forms of indirect expression, like allusions and metaphors. Cultural coverage of the period under research was delivered by newspapers: Národní listy (National Papers), Lidové noviny (Public News), Naše doba (Our Time), Venkov (Country), etc. Theatre reviews were usually published in regular columns entitled "Theatre and Arts" and "Science, Literature and Arts". The most influential wartime critics were Jindřich Vodák (1867-1940), literary and theatre critic, and Otokar Fischer (1883-1938), literary and theatre critic, historian, German scholar, translator, poet and dramaturge. Critical notes were also written by František Václav Krejčí (1867-1941), novelist, journalist, critic and politician, and Jaroslav Hilbert (1871-1936), critic, playwright and novelist. Short announcements were usually anonymous. Though apparently, Czech culture and theatre during the Great War were not silent, but only made to speak more quietly at first. In the course of time, their voice gradually became more powerful and resounding.

\section{Shakespeare as a symbol of the Czech pro-Allied attitude}

In the second year of the Great War, the world commemorated the tercentennial anniversary of Shakespeare's death. As Ladina Bezzola Lambert and Balz Engler (2004: 81) pointed out, the commemoration of the poet's death in Britain epitomized the defence of the spiritual property of the nation, threatened by a German invasion. Similarly, Shakespeare's tercentenary celebration in the Czech Lands was understood not only as a great theatrical achievement, but most importantly as a presentation of the Czech national self-awareness and identity. It furthermore attempted to strengthen 
the autonomy of the Czech theatres and demonstrated the Czech pro-Allied sympathies during days that were marked by the omnipresent hostile exhortation "Gott strafes England". Shakespeare thus became both a symbolic and actual ally in the struggle for cultural self-expression and autonomy. ${ }^{4}$ In Jan Mukařovský's view (in Nicoll 1956: 108), Shakespeare's glorification on that occasion was incomparable to any other European theatrical event of that particular time.

This magnificent theatrical achievement would not be possible without Jaroslav Kvapil's enthusiasm and dedication (Mišterová 2010: 179). A significant figure in the Czech theatrical scene, Kvapil was an outspoken actor, director, translator, poet, and playwright who was at the forefront of the secret Czech resistance movement called Maffia. Throughout his career as an actor and director, Kvapil (1868-1950) placed special emphasis on Shakespeare's work, which became the cornerstone of his drama company's repertoire. Kvapil's most valuable performances were Hamlet (1905, 1915), Richard III (1916), and Macbeth (1916). ${ }^{5}$

The Shakespeare festival was inaugurated on 27 March 1916 with Smetana's triumphal overture in $\mathrm{C}$ major conducted by the famous Czech composer and conductor, Karel Kovařovic, which was followed by an introductory address delivered by F. X. Šalda, the renowned Czech art critic. In his speech entitled Genius Shakespearưv a jeho tvorba: Apostrofa kritická (Shakespeare, the Genius, and His Oeuvre: the Critical Apostrophe), Šalda (1916: 18) provided a complex insight into Shakespeare's drama, which he saw as a "living and flowing system" in which individual elements were interconnected and interdependent, thereby creating full and complex dramatic characters. He further underscored Shakespeare's unequalled eloquence and his extraordinary skill in contriving dramatic situations and creating plausible dramatis personae. The reviews concerning the festival's opening expressed the hope that it would achieve universal popularity. Simultaneously it was also portrayed as in direct descent from the previous Shakespeare festival, which had taken place in Prague in 1864.

The Shakespeare cycle ran from 27 March to 4 May 1916. In cooperation with Eduard Vojan, the mainstay of his drama company, Kvapil had prepared a rich programme of seventeen plays in Josef Václav Sládek's translations. Yet the Censor's office eventually reduced the number of productions to fifteen. ${ }^{6}$ The initially planned performance of King John, employing a symbolic image of Austria's severed head, was banned due to the rigid censorship. The premiere of both parts of Henry IV was first allowed an exception, but was later postponed to the autumn (see below).

In the increasingly tense wartime atmosphere of the mid-1920s, the audience's attention was focused particularly on the second production of the cycle, Richard $I I I$, in which the director laid emphasis on the power struggle motivated by personal ambition and a desire for profit and glory. He underscored Richard III's rise to the throne and his inevitable fall through symbolist stage design, using a large set of stairs covered by red cloth. A similar stage design was used in 1920 by Leopold Jessner, whose production of Richard III at Staatliches Schauspielhaus in Berlin was considered to be "the first [German] attempt to relate Richard III to the modern politics" (Jowett 2000: 96). Due to censorship, reviewers did not 
attribute the performance's success to its political appeal but to Eduard Vojan's psychologically realistic acting which combined non-verbal communication with finely chiselled details. The performance was, indeed, also characterised by Vojan's engaging interpretation of the role. According to Vodák (1916a: 2), Vojan managed to grasp Richard's "Epicurean hypocrisy" in its complexity and to carry it out with extraordinary gusto. He showed a wide range of Richard's emotions through his facial expressions. Thanks to Vojan's rendition, the borders between art and reality were probably blurred, and the audience was invited to share a (political) message, which was born out of Shakespeare's words.

Vojan used his psychological-realistic acting style also in his portrayal of Shylock. Although the details of his gestures, movements, body language and overall appearance evoked Shylock's Jewishness, Vojan's Shylock was above all "a wholly insidious being; full of hatred and devilishly vindictive, whose irreconcilable anger menaces and screams with voracious savagery" (Vodák 1950: 129, translation author). However, Vojan did not neglect to portray Shylock's isolation and suffering, which he transformed into the reproach and condemnation of the surrounding world. Otokar Fischer perceived him in a similar manner, as he accepted Vojan's authenticity, flexibility, diversity and tragic grandeur. In Fischer's eyes, Shylock was not a savage or vengeful being; nor was he a hero, but a deeply suffering human being:

Vojan's performance jumps quickly from the pain of Shylock's fugitive daughter to his pain over lost money, from avarice to sadness, from desperation to flashes of vengefulness. What we always emphasise in Vojan's performances is becoming clearer and clearer: his exceptional human understanding of happiness and tragedy, his humane empathy, his theatrical complements and his recreation of Czech humane philosophy. Not a grotesque Jew, not a despicable usurer, not a programmed speaker for philosemitic principles (as was the case with more recent portrayals of Shylock), but a human, as most closely depicted in his own interpretation: an unhappy father whose own daughter was snatched from him; an exile from society in which the decades-long woes of his tribe are gathered and vented.

(Fischer 1916a: 4, translation author)

Fischer's review seems to aptly describe Vojan's Shylock, who was neither a villain nor a hero, but a desperate and humiliated man. Vojan obviously shifted the focus from Shylock's status as a villain to that of a suffering father and an ordinary man, who carried his weaknesses with him. His Shylock does not seem to have fallen prey to his revengefulness but rather to circumstances (and external causes). This change of focus from "villainy" to a flawed "humanity" was obviously understood by wartime audiences who probably associated Shylock's suffering with any injustice, misery, and perhaps the tragedy of war. The performance, no doubt, gained emotional force. According to Vodák (1950: 123), the entire audience felt for Shylock at the moment of his humiliation and 
applauded appreciatively. Positive period reviews perceived Vojan's performance as unrivalled. It is not surprising, then, that not many of Vojan's contemporaries (Šmaha, Fencl) or followers (Hurt, who was even reluctant to assume the role) could achieve the complexity of Vojan's rendition.

It should not go without a mention that Antonín Fencl's performance of The Merchant of Venice [Benátský kupec] premiered at the Smíchov Amphitheatre on 8 April $1916 .{ }^{7}$ Interestingly enough, Kvapil's and Fencl's respective performances of The Merchant of Venice were divided by only a single day. This situation was probably a matter of duplicity both in terms of time and competition, as Fencl's rendition differed significantly from Kvapil's version. Fencl became the exclusive and multifunctional creator of the performance, in which he rose to the task of director, stage designer, translator and performer of the role of Shylock. In contrast to Kvapil's directing concept and Vojan's artistic rendition, Fencl portrayed Shylock as a comic character and highlighted the figure's distinctness. Nevertheless, he also emphasised Shylock's Jewishness by giving him various stereotypical visual attributes, i.e. with a turban, curly locks flowing down his temples, and wearing a beard. He was dressed in a decorative but rather simple manner, all of which contrasted with the elegant and expensive clothing worn by Christians. ${ }^{8}$

Reviews from the time differed in their evaluation of the performance. Fencl's "little Jew, who not long before was still running about with 'a bag of skins", was given the only positive evaluation by Vodák, who furthermore highlighted the differences between Vojan and Fencl's concept of the character. Whereas Vojan's Shylock towered over his surroundings and overshadowed all those who crossed his path as weak and worthless dwarves, Fencl "has taken his Shylock down to the level of everyday world end even below it" (Vodák 1950: 129, translation author). Fencl's version of The Merchant of Venice was surely non-traditional and, in many ways, controversial. This is reflected in theatre reviews of the time, which split the play into two camps. Contrary to Vodák's positive summary, which does not deny the particularity and detail of Fencl's version, Otokar Fischer (1916a: 4) and Hanuš Jelínek (1916: 237) reject the comic interpretation of Shylock's character, accented by racial features, and the trial scene as an expression of "primitive naturalism".

From today's point of view, it is difficult to judge which of the critics most accurately reviewed the essence of Fencl's The Merchant of Venice and whether the performance was truly a misunderstood work of the director's inventiveness for which the audience, used to Vojan's monumental characters, was not prepared, or an unsuccessful and erroneous misinterpretation of Shakespeare's play. After eight showings, the performance was taken off the programme. This, however, was not necessarily done because the play was unsuccessful, although Fencl's translation never saw another performance (see Drábek 2012: 166-167).

Symptomatic of Vojan's psychological-realistic acting was his rendition of Hamlet. He imbued the Danish prince with psychological motivation and nonverbal communication, and embodied him as a complex and multilayered figure. As the reviews demonstrate, he played a melancholic prince, who was isolated 
from others by the nobility of his soul and the intensity of his grief. He was not a man of action but a contemplative individual of deep thought and biting irony (K[rejčí 1915: 8). Theatre critics even commented upon a symbiotic relationship existing between Vojan and Hamlet. At the same time, the director placed more emphasis on the social and political relevance of the play, evidence of which can be found in the re-enacted Fortinbras scene that carried a veiled warning against a new ruler's succession to the throne. In all previous performances (17 October 1915-4 February 1916), his part had been dropped. The performance of Hamlet was thus invested with new political resonance.

Macbeth was one of the greatest attractions of the festival. It profited from spatial simplicity and minimal set design. It was staged on an empty plain surrounded by a plastic hilly area with a grey horizon, over which dim shadows of the witches were flying. With Vojan in the leading role, it was immensely successful. His interpretation seemed most plausible after the murder of the king. To Jindřich Vodák (1950: 122), he was both a warlike creature and an introverted man, who finally collapsed into "a common humanity". The review seems to suggest that the performance might have been approached (at least partly) as a "melodrama" of the rise and fall of a monarch and his wife. As Lady Macbeth, Leopolda Dostalová brought a combination of her personal beauty, dominance and tenderness to the role that made her husband's capitulation to her credible (Krejčí 1916: 8). Dressed in a white dress, which contrasted with the dense black background, Dostalová was especially convincing in the sleepwalking scene.

The Shakespeare festival was symbolically brought to an end by Henry $I V$, with both parts compressed into one evening. The production represented a serious menace to the monarchy even though it was marked by considerable cuts, which led to the downplaying of the major political issue of the play. There was the threat that the spectacularly staged coronation scenes might have been connected with rumours that the new independent Czech state was to be ruled by one of the sons of George $V$ of England. The production was dominated by the figure of Falstaff (Richard Schlaghammer), portrayed as a traditional protagonist, typical of the nineteenth century comedies. Overwhelmed by Falstaff's monumental presence and his humour, the audience "did not even notice the intricate political implications of the Falstaff-Hall relationship" (Procházka 1996: 52). The production, however, climaxed in the aforementioned coronation scene that symbolised the longstanding Czech aspirations for national sovereignty. The royal inauguration, accompanied by the act of handing over of the royal insignia, represented a theatrical act of symbolic recreation of the nation.

\section{Conclusion: the Shakespeare festival, praise and criticism}

The way a particular dramatic text is decoded depends, among others, on the recipient, whose role is to actively reconstruct the meaning of the work. Thus, the text/performance may be viewed as a set of expectations that are fulfilled, 
modified or thwarted by the recipient through his/her own "problem-solving faculties". The process of understanding (= completion) is, moreover, to a considerable degree, affected by the way the recipient is situated in the world. Thus, the overall reception is influenced by temporal, cultural and even geo-political factors, as well as the personal abilities of the recipient.

During the Great War, audiences tended to find more politically questionable meanings in plays, or rather, theatrical productions, and the theatre was ascribed more power in terms of its ability to affect the public. The repertoire consisted largely of Czech classics, which aroused national feelings and affection for the Czech Lands (Bohemia). Although Shakespeare's work was, at the time, regarded as "hostile", it retained its important place in the repertoire of Czech theatres. In many ways, it became synonymous with the pro-Allied attitude of the Czechs. It was probably for these reasons that the Shakespeare festival, which was meant to celebrate the tercentenary of Shakespeare's death in 1916, had initially been banned by the authorities and was permitted only later due to the prompt and quick-witted director's argumentation and diplomatic skills. However, the official approval for the festival did not exempt it from strict censorship regulations, which were applied at the time. Even the opening lecture delivered by F. X. Šalda was published in a highly censored and truncated form.

The key performer of the festival was undoubtedly Eduard Vojan. His combination of psychological, visually attractive, nuanced acting and vivid nonverbal communication made his Shakespearean renditions especially powerful and impressive. During the festival, he played the parts of Shylock, Lear, Hamlet, Macbeth, Othello, Richard, Petruchio, and Benedick. He was praised particularly for his performance as Shylock, whom he rendered as a comprehensible human being, a desperate father, who had lost his daughter and an expatriate from society. The critics perceived Vojan's Shylock as "realistic" and "unrivalled". The production was both a critical and a popular success.

The important feature of the festival was its universal appeal. Despite wartime shortages and hardships, audiences from various strata of society attended the festival and enjoyed Shakespearean productions expertly directed by Jaroslav Kvapil. The size of the audience can only be estimated, but the majority of performances were sold out and the newspapers reported on attentive and enthusiastic audiences. Period reviews repeatedly mentioned that theatrical productions attracted unusual attention from spectators from all strata of society, who regularly filled the theatre plein comme un oeuf during the festival (Vodák 1916b: 4).

With respect to strict censorship, to most reviewers at that time, the festival was a significant cultural event (Fischer 1916b: 4). The predominant panegyric rhetoric framing the Shakespeare Festival in newspaper reviews highlights the importance of the Bard for Czech culture. Later, commentators were obviously more concerned with the festival's political character and saw it as a "silent political protest" (Šalda 1961: 240), a "political event of considerable extent" (Fischer 1919: 198) and "an act of courage and faith which was fully justified by the results" (Vočadlo 1956: 108). The festival obviously proved itself as a demonstration of the spirit of the nation. 
Yet, it did not escape criticism for the over-refined (or even academic) concept of productions marked by a "boarding school decorum", as Jindřich Vodák (1916c: 3 ) called it, which was probably perceived as outdated in the context of the newly emerging symbolist expressionism pioneered by Karel Hugo Hilar at the Vinohrady Theatre in Prague. However, as each reviewer brought a different set of experiences and a different horizon of expectations to the performance, each review should be (at least partially) considered to be subjectively conditioned.

The festival was also criticised for presenting Shakespeare as "eternal". The Bard's plays were, moreover, regarded as "anachronistic" and having nothing to say to the contemporary public. Fondness for Shakespeare's work was ascribed only to "blind literary enthusiasts" and "literary hypocrites" (Hilbert 1916: 9). Besides, Shakespeare festivals held at the National Theatre to celebrate Shakespeare's anniversaries in 1864 and 1916 were considered an obstacle to the development of new Czech drama (apparently the critic's own plays), which had (and with vain effort) sought to be performed on the first stage. This distorted anti-Shakespearean rhetoric obviously served its own purpose.

Another remarkable theatrical event of the time was Antonín Fencl's production of The Merchant of Venice. Fencl's stage-centred translation, which drew from his experience as an actor, director, translator and playwright, attended mainly to the theatrical needs and performability of the text. Although Fencl received favourable reviews for his fluent and speakable translation, the reviews of his directing concept were far from good. There was almost a general disapproval of his comic rendition of Shylock. The criticism was probably further heightened by a strong contrast between Fencl's "tiny Jew with a squeaky voice" and Vojan's "magnificent" Shylock. The production was removed from the repertoire after eight performances and the translation has not been used since.

During the war, the theatre played a fundamental role of spiritus agens, both in the cultural as well as political life of the country. It served as an effective mode of communication, often addressing the audience with the secret language of irony and metaphor. The stage became a locus communis where audiences were symbolically confronted with the actuality of war through the fictional world of the play, thus, politicising the live theatre space. Theatrical performances represented cultural events, which were an integral part of the overall cultural and socio-political background. They manifested a need for independence from AustriaHungary and overtly expressed the national spirit. Moreover, they demonstrated that, during the Great War, muses in the Czech Lands were not silent but, quite the opposite, raised their voices in support of the Czech nation and Czech culture.

\section{Notes}

The last military conflict, in which the Czech Lands were involved, took place in 1866. Even though Jauss and Iser both intended to shape the newly emerging critical approach to the study of literature and attempted to re-evaluate the canon, their starting points and ways of achieving this aim were different (Holub 1995: 327). Whereas the Romance language scholar 
Jauss drew on hermeneutics, and particularly Hans-Georg Gadamer, the Anglicist Iser was influenced mainly by phenomenology and its major representative Roman Ingarden. Another distinction lies in their scope of activity. Unlike Jauss's broader concern with historical and social nature, Iser's focus was on the individual text and the way it related to its recipients. Text and performance can be, figuratively speaking, perceived as two sides of the same coin, which do not necessarily arise together but exist in a mutual synergy; they are interconnected and can be defined in terms of each other. Nevertheless, opinions differ on the nature of the text-performance relationship and its importance. In this article, a dramatic text is perceived as both an integral part of literary canon and subject to textual analysis as well as a constituent of performance.

4 This article is a part of broader research that focuses on English and American productions, with an emphasis on Shakespearean productions on Czech theatre stages during the Great War.

5 From 1900, Kvapil developed his own directing style at the National Theatre. It combined elements of Symbolism and Impressionism.

$6 \quad$ The festival ran from 27 March to 4 May 1916, with productions of The Comedy of Errors (27 March), Richard III (30 March), Romeo and Juliet (1 April), A Midsummer Night's Dream (4 April), The Merchant of Venice (7 April), The Taming of the Shrew (9 April), Much Ado about Nothing (13 April), As You Like It (15 April), Measure for Measure (17 April), Twelfth Night (19 April), Hamlet (23 April), King Lear (25 April), Macbeth (28 April), Othello (30 April) and The Winter's Tale (4 May).

7 Fencl mainly highlighted the practical organisation of the stage with the Venetian street in the foreground and the changing spaces of the yellow coloured Belmont, the dark interior of Shylock's home, the courtroom, or the starry sky above Belmont in the background, which allowed for fluent changes in scenes without needless delays in time, omissions of text or changes in the sequence of scenes, as was the case, in Vodák's view (1950: 127-128), with versions of the play by Kvapil or Reinhardt.

Fencl's actual age disrupted the traditionally perceived image of Shylock as an older man. Although Shylock's calendar age is not explicitly mentioned in the play (aside from the fact that he has a daughter), Shylock's youthful appearance made a rather surprising impression especially when considering the context of Vojan's older portrayal of Shylock. Fencl, at the time of the premiere, was 34 years old, while Vojan was almost twice that age at the time of his performance of Shakespeare's play. The use of a mask cannot be ruled out, however, Vodák's list of Shylock's physical activities ("running, cringing, dodging, happily prancing, clapping, folding his body and wriggling like a hamster") imply more youthful and active behaviour.

\section{Acknowledgements}

\section{This article was supported by The Czech Science Foundation project GA406-13- 14048S Anglo-American Drama in Czech Theatres during the Great War.}

\section{References}

Bennett, Susan (2003) Theatre Audiences. A Theory of Production and Reception. $2^{\text {nd }}$ ed. Abingdon and New York: Routledge.

Bezzola Lambert, Ladina and Balz Engler (2004) Shifting the Scene: Shakespeare in European Culture. Newark: University of Delaware Press.

Črnej, Petr (1992) Fundamentals of Czech History. Praha: Práh. 
Drábek, Pavel (2012) České pokusy o Shakespeara [Czech Attempts at Shakespeare]. Brno: Host.

Fischer, Otokar (1916a) "Divadlo a hudba. Shakespearův cyklus Národního divadla." [Theatre and Music. Shakespeare Cycle at the National Theatre] Národní listy 56 (101): 4.

Fischer Otokar (1916b) "Divadlo a hudba." [Theatre and Music] Národni listy 56 (125): 4.

Fischer, Otokar (1919) K dramatu. Problémy a výhledy [On the Czech Drama. Problems and Prospects]. Praha: Grosman a Svoboda.

Freshwater, Helen (2009) Theatre Audiences. London: Macmillan.

Hardwick, Lorna (2003) Reception Studies. Oxford: Oxford University Press.

Hilbert, Jaroslav (1916) "Několik poznámek po dokončení Shakespearova cyklu.” [A few Remarks after the Closing of the Shakespeare's Cycle] Venkov 11 (108): 9.

Holub, Robert C. (1995) "Reception Theory: School of Constance." In: Selden, Raman (ed.) The Cambridge History of Literary Criticism. Volume VIII. From Formalism to Poststructuralism. Cambridge: Cambridge University Press, 319-346.

Iser, Wolfgang (1993) Prospecting from Reader Response to Literary Anthropology. Baltimore: The Johns Hopkins University Press.

Jauss, Hans Robert (2007) Toward an Aesthetic of Reception. Translated by Timothy Bahti. $8^{\text {th }}$ ed. Minneapolis: University of Minnesota Press.

Jelínek, Hanuš (1916) “Divadlo. Benátský kupec na Smíchově." [Theatre. The Merchant of Venice at the Smíchov Theatre] Lumir 44 (5): 237.

Jowett, John, ed. (2000) The Tragedy of King Richard III. Oxford: Oxford University Press.

K[rejčí], František Václav (1915) "Shakespearův Hamlet v novém nastudování 17. rŕjna." [Shakespeare's Hamlet] Právo lidu XXIV (289): 8.

Krejčí, František Václav (1916) "Literatura a umění. Macbeth.” Právo lidu XXV (60): 7-8.

Mišterová, Ivona (2010) "Translation and Performance: the Presentation of Shakespeare in Pilsen in the Context of Social and Political Events in the 20th and 21st Centuries." Brno Studies in English 36 (1), 175-189.

Nicoll, Allardyce, ed. (1956) Shakespeare Survey 9. Cambridge: Cambridge University Press.

Nünning, Ansgar, Jiří Trávníček and Jiří Holý (2006) Lexikon teorie literatury a kultury [An Anthology of Literary and Cultural Theory]. Brno: Host.

Pavis, Patrice (1982) Languages of the Stage. Essays in the Semiology of the Theatre. New York: Performing Arts Journal Publications.

Procházka, Martin (1996) "Shakespeare and Czech Resistance." In: Kerr, Heather, Robin Eaden and Madge Mitton (eds.) Shakespeare: World Views. Newark, London: Associated University Presses, 44-70.

Rush, Ormond (1997) The Reception of Doctrine. An Appropriation of Hans Robert Jauss' Reception Aesthetics and Literary Hermeneutics. Roma: Gregorian University Press.

Selden, Raman, Peter Widdowson and Peter Brooker (2005) A Reader's Guide to Contemporary Literary Theory. $5^{\text {th }}$ ed. Harlow: Pearson Education Limited.

Šalda, František Xaver (1916) Genius Shakespearův a jeho tvorba: Apostrofa kritická [Shakespeare, the Genius, and His Oeuvre: the Critical Apostrophe]. Praha: František Borový.

Šalda, František Xaver (1961) "O naší moderní kultuře divadelně dramatické." [On our Modern Theatrical and Dramatic Culture] In: Studie z české literatury. Soubor díla F. X. Šaldy. Volume VIII. Praha: Československý spisovatel, 206-232.

Šedivý, Ivan (2001) Češi, České země a velká válka 1914-1918 [Czechs, Czech Lands and the Great War 1914-1918]. Praha: Nakladatelství Lidové noviny.

Vočadlo, Otakar (1956) "Shakespeare and Bohemia." In: Nicoll, Allardyce (ed.) Shakespeare Survey. Cambridge: Cambridge University Press, 101-110.

Vodák, Jindřich (1916a) "Poznámka o Shakespearově Richardu III." [A Note on Shakespeare's Richard III] Lidové noviny 24 (93): 2-3.

Vodák, Jindřich (1916b) “Shakespearův cyklus v Praze.” [Shakespeare’s festival in Prague] Lidové noviny 24 (88): 2-3. 
Vodák, Jindřich (1916c) "Další drobty shakespeareské [sic].” [Other Shakespearean 'Crumbs'] Lidové noviny 24 (118): 2-3.

Vodák, Jindřich (1950) Shakespeare: Kritikưv breviář [Shakespeare: Critic's Breviary]. Praha: Melantrich.

Ivona Mišterová is a senior lecturer at the Department of English language and literature at the University of West Bohemia in Pilsen. She received her Ph.D. in English and American Literature from Charles University in Prague. She conducts research in the area of theatrical interpretations of English and American plays performed in Czech theatres in the twentieth century. She has published monographs Shakespeare's Plays Performed in Pilsen (2005) and The Reception of AngloAmerican Drama on Pilsen Stages (2013).

Address: PhDr. Ivona Mišterová, PhD., Department of English Language and Literature, Faculty of Philosophy and Arts, University of West Bohemia in Pilsen, Sedláčkova 15, 30614 Pilsen, Czech Republic. [email: yvonne@kaj.zcu.cz] 
